\title{
KOMUNIKASI PARTISIPATIF DALAM PELAKSANAAN PRIMA TANI DI KECAMATAN SUNGAI KAKAP KABUPATEN PONTIANAK
}

\author{
Risyart A. Far Far \\ Staf Pengajar FAPERTA UNPATTI-Ambon,e-mail: duniaalberthfarfar@yahoo.co.id
}

\begin{abstract}
ABSTRAK
Mengatasi permasalahan lambannya penyampaian informasi dan rendahnya tingkat adopsi inovasi teknologi yang dihasilkan oleh Badan Litbang Pertanian,maka tahun 2005 dilaksanakan Program Rintisan dan Akselerasi Pemasyarakatan Inovasi Teknologi Pertanian (Prima Tani). Suatu model atau konsep baru diseminasi teknologi untuk mempercepat penyampaian informasi, bahan dasar inovasi yang dihasilkan oleh Badan Litbang Pertanian. Desa Sungai Itik Kecamatan Sungai Kakap Kabupaten Pontianak dengan karakteristik lokasi sebagai lahan rawa/pasang surut merupakan salah satu desa yang ditetapkan sebagai lokasi Prima Tani. Lahan pasang surut ini diusahakan secara intensif oleh masyarakat, namun produksinya masih terbatas disebabkan kondisi lahannya kurang mendukung untuk pertumbuhan tanaman. Salah satu upaya yang dapat dilakukan untuk mengatasi permasalahan tersebut adalah melalui Prima Tani. Proses mengenali, merencanakan dan melaksanakan model usahatani dalam Prima Tani menggunakan proses komunikasi yang partisipatif karena melibatkan masyarakat dalam pengambilan keputusan. Penelitian ini bertujuan untuk: a) Mengetahui komunikasi partisipatif dalam pelaksanaan Prima Tani di Desa Sungai Itik Kecamatan Sungai Kakap, b) Menganalisis hubungan antara karakteristik individu petani dengan komunikasi partisipatif dalam pelaksanaan Prima Tani di Desa Sungai Itik Kecamatan Sungai Kakap. Penelitian ini dirancang sebagai survey yang bersifat deskriptif korelasional dan dilaksanakan pada bulan Juni sampai dengan Agustus 2008. Hasil penelitian menunjukkan bahwa Komunikasi Partisipatif dalam pelaksanaan Prima Tani terbukti efektif dalam meningkatkan pengetahuan dan sikap petani terhadap model usahatani terpadu dalam pelaksanaan Prima Tani. Karakteristik individu petani mempunyai hubungan nyata dengan komunikasi partisipatif dalam pelaksanaan Prima Tani untuk beberapa peubah antara lain: Motivasi berhubungan nyata dengan penumbuhan ide. Tingkat Pendapatan petani berhubungan nyata dengan perencanaan program, berhubungan sangat nyata dengan pelaksanaan program dan berhubungan nyata dengan penilaian program.
\end{abstract}

Kata Kunci: Karakteristik individu, Komunikasi partisipatif

\section{PENDAHULUAN}

\subsection{Latar Belakang Penelitian}

Pembangunan pertanian di Indonesia pada awalnya adalah sangat sentralistis dan cenderung top down, dan pola ini diakui memang telah banyak membawa perubahan dan kemajuan pembangunan pertanian di Indonesia pada umumnya. Di sisi lain pola ini juga banyak menimbulkan masalah pembangunan pertanian seperti ketergantungan petani terhadap bantuan pemerintah sangat tinggi, kemandirian masyarakat menjadi sangat rendah dan potensi yang ada pada akhirnya menjadi tidak berkembang.

Berdasarkan pengalaman tersebut memasuki awal tahun 1993 paradigma pembangunan pertanian di Indonesia telah mengalami pergeseran dari pendekatan peningkatan produksi ke pendekatan yang mengarah pada pendapatan dan kesejahteraan keluarga petani. Pembangunan pertanian diarahkan pada potensi daerah dengan mengembangkan kebijakan desentralisasi mulai dari perencanaan hingga pelaksanaannya, 
sehingga setiap program pengembangan pertanian dapat menyesuaikan dengan kondisi spesifik lokasi wilayah .

Sejalan dengan itu, untuk mendukung suatu pengembangan usaha agribisnis yang berdaya saing, maka Departemen Pertanian telah membentuk Balai Pengkajian Teknologi Pertanian (BPTP) di setiap Provinsi, salah satunya adalah di Provinsi Kalimantan Barat yang merupakan Unit Pelaksana Teknis Pusat yang berada di daerah dan bertangung jawab langsung kepada Badan Penelitian dan Pengembangan Pertanian di tingkat pusat.

Evaluasi eksternal maupun internal menunjukkan bahwa kecepatan dan tingkat pemanfaatan adopsi inovasi yang dihasilkan Badan Penelitian dan Pengembangan Pertanian cenderung lamban bahkan menurun (BPTP Kalbar, 2005). Untuk mengatasi permasalahan lambannya penyampaian informasi dan rendahnya tingkat adopsi inovasi, mulai tahun 2005 Badan Penelitian dan Pengembangan Pertanian melaksanakan Program Rintisan dan Akselerasi Pemasyarakatan Inovasi Teknologi Pertanian (Prima Tani), suatu model atau konsep baru diseminasi teknologi yang dipandang perlu, mampu dan dapat mempercepat penyampaian informasi, bahan dasar inovasi baru yang dihasilkan oleh Badan Penelitian dan Pengembangan Pertanian (BPTP Kalbar, 2005). Program ini pada tahap awal dilaksanakan pada 14 Provinsi di Indonesia, salah satunya adalah di Provinsi Kalimantan Barat, dengan lokasi pada lahan rawa/pasang surut di Desa Sungai Itik Kecamatan Sungai Kakap Kabupaten Pontianak.

Lahan pasang surut mempunyai karakteristik yang berbeda dibandingkan dengan lahan pertanian pada umumnya. Lahan ini merupakan daerah rawa yang dipengaruhi oleh pasang surut air laut, di mana terletak pada dataran pantai dengan tanah gambut atau mineral atau campuran keduanya serta memiliki kondisi tanah yang relatif kurang subur. Desa Sungai Itik sebagai desa dengan karakteristik lahan pasang surut merupakan salah satu desa di Kecamatan Sungai Kakap yang lahan pertaniannya diusahakan secara intensif, namun produksinya masih terbatas karena disebabkan oleh kondisi lahannya yang kurang mendukung untuk pertumbuhan suatu tanaman. Hal ini disebabkan karena reaksi tanahnya yang sangat asam atau $\mathrm{pH}$ tanahnya rendah sehingga menyebabkan tanaman sering keracunan besi $(\mathrm{Fe})$, kekurangan unsur hara makro dan mikro lainnya yang diperlukan tanaman. Akibatnya tanaman kurang subur sehingga produktivitas rendah, pada akhirnya tingkat pendapatan petani menjadi rendah. Kondisi ini menggambarkan pentingnya bagi petani untuk mendapatkan bantuan informasi dan teknologi tepat guna, permodalan dan informasi pasar untuk memasarkan hasil produksinya sehingga tercapai peningkatan hasil usahatani dan pendapatannya.

Untuk mengatasi permasalahan tersebut, maka salah satu upaya yang dapat dilakukan oleh pemerintah khususnya Balai Pengkajian Teknologi Pertanian adalah melalui Prima Tani, karena tujuan utama Prima Tani adalah untuk mempercepat waktu dan memperluas adopsi inovasi pertanian yang dihasilkan oleh Badan Penelitian dan Pengembangan Pertanian yang disesuaikan dengan karakteristik lokal spesifik sesuai dengan penggunanya (petani). Salah satu cara untuk memotivasi dan memfasilitasi masyarakat tani untuk secara partisipatif membangun pertanian wilayah adalah melalui percepatan pemasyarakatan inovasi teknologi dan kelembagaan pertanian dengan memberdayakan potensi sumber daya lokal (Deptan, 2006). Prima Tani direncanakan dari dan oleh masyarakat tani bersama pemangku kepentingan pembangunan pertanian masyarakat pedesaan. Mengacu pada kenyataan tersebut maka pendekatan komunikasi dalam Prima Tani adalah melibatkan berbagai unsur dari Pemerintah, dalam hal ini Dinas/Instansi terkait mulai dari provinsi, kabupaten, kecamatan, desa dan swasta serta petani sebagai sasaran program. Melalui komunikasi yang partisipatif sesuai dengan tahapan dalam Prima Tani, maka masyarakat diajak untuk turut bersama-sama pemerintah untuk merencanakan apa yang menjadi kebutuhan dan keinginannya, melaksanakan dan memberikan penilaian terhadap apa yang akan dan telah dilaksanakannya. Berdasarkan hal tersebut, maka penelitian ini dianggap perlu agar program Prima Tani dapat lebih dikembangkan lagi.

\subsection{Tujuan Penelitian} untuk:

Secara spesifik penelitian ini bertujuan

1. Mengetahui komunikasi partisipatif dalam pelaksanaan Prima Tani di Desa Sungai Itik Kecamatan Sungai Kakap Kabupaten Pontianak.

2. Menganalisis hubungan antara karakteristik individu petani dengan komunikasi partisipatif dalam pelaksanaan Prima Tani di 
Desa Sungai Itik Kecamatan Sungai Kakap Kabupaten Pontianak.

\section{KERANGKA PEMIKIRAN HIPOTESIS}

\subsection{Kerangka Pemikiran}

Komunikasi partisipatif dalam Prima Tani yang dilaksanakan di desa Sungai Itik Kecamatan Sungai Kakap dipengaruhi oleh karakteristik individu petani itu sendiri. Faktor karakteristik

\begin{tabular}{|c|}
\hline $\begin{array}{ll}\mathrm{X}_{1 .} & \begin{array}{l}\text { Karakteristik } \\
\text { individupetani }\end{array}\end{array}$ \\
\hline 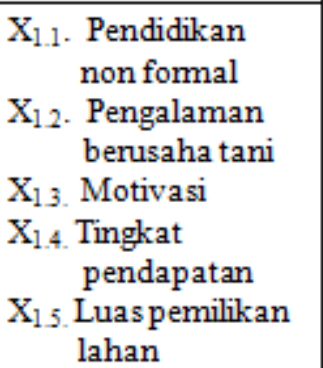 \\
\hline
\end{tabular}

individu petani ( pendidikan formal, pengalaman berusaha tani, motivasi, tingkat pendapatan dan luas pemilikan lahan) akan mempengaruhi proses komunikasi partisipatif (penumbuhan ide, perencanaan program, pelaksanaan program yang dihasilkan, penilaian terhadap program yang dilaksanakan) dalam Prima Tani. Hubungan antara kedua faktor di atas dapat dilihat pada Gambar 1.
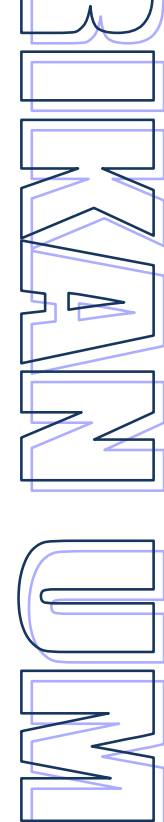

Gambar 1 Hubungan antara Peubah Penelitian

\subsection{Hipotesis Penelitian}

Berdasarkan permasalahan dan kerangka pemikiran yang telah dikemukakan, maka hipotesis penelitian ini dapat dirumuskan sebagai berikut:

$\mathrm{H}_{1}$ : Ada hubungan yang nyata antara karakteristik individu petani (usia, pendidikan, pendidikan non formal, pengalaman berusaha tani, motivasi, luas pemilikan lahan, tingkat pendapatan dan keanggotaan dalam kelompok tani) dengan komunikasi partisipatif dalam pelaksanaan Prima Tani (penumbuhan ide, perencanaan program, pelaksanaan program yang dihasilkan, penilaian pelaksanaan program yang dihasilkan).

\section{METODE PENELITIAN \\ 3.1. Desain Penelitian}

Penelitian ini didesain sebagai penelitian survei yang yang bersifat deskriptif korelasional. Menurut Singarimbun dan Effendi (1989), desain penelitian survei adalah penelitian yang mengambil contoh dari suatu populasi dan menggunakan kuesioner sebagai alat pengumpulan data yang pokok. Data yang terkumpul meliputi data primer dan sekunder baik bersifat kualitatif maupun kuantitatif. Oleh karena itu, penelitian ini mendeskripsikan peubah peubah seperti karakteristik individu petani, komunikasi partisipatif dalam pelaksanaan Prima Tani serta menguji hipotesis yang telah dirumuskan.

\subsection{Lokasi dan Waktu penelitian}

Penelitian ini dilaksanakan di Desa Sungai Itik Kecamatan Sungai Kakap Kabupaten Pontianak Propinsi Kalimantan Barat. Pemilihan lokasi penelitian dilakukan secara sengaja ( purposive ). Alasan pemilihan lokasi karena Desa Sungai Itik merupakan wilayah yang pertama kali ditetapkan sebagai lokasi Prima Tani. Waktu yang digunakan untuk pengumpulan data selama 3 bulan, terhitung mulai dari bulan Juni 2008 sampai dengan Agustus 2008.

\subsection{Populasi dan Sampel penelitian}

Populasi (Riduwan, 2004), merupakan obyek atau subyek yang berada pada suatu wilayah dan memenuhi syarat-syarat tertentu berkaitan dengan masalah penelitian. Terkait dengan tujuan penelitian, maka populasi dalam penelitian adalah seluruh petani yang tergabung dalam kelompok tani berjumlah 17 kelompok 
dengan jumlah keseluruhan anggota 502 orang serta berdomisili di Desa Sungai Itik.

Responden yang dimaksud dalam penelitian ini adalah anggota kelompok tani. Jumlah responden yang dijadikan sampel dalam penelitian adalah sebanyak 100 orang. Untuk objektivitas informasi yang diperoleh dari sumber sekunder, maka beberapa sumber yang dianggap dapat mewakili untuk dijadikan sumber informasi, yaitu: (a) tokoh kunci informal dan formal masyarakat setempat, kepala desa (b) penyuluh, (c) UPTD Pertanian Kecamatan dan (d) BPTP yang secara fungsional menangani prima tani.

\subsection{Teknik Penarikan Sampel}

Didasarkan pada besarnya populasi penelitian, dan kemampuan peneliti baik dana, waktu maupun tenaga maka untuk keperluan penelitian dilakukan penarikan sampel. Pemilihan kelompok tani dan anggota kelompok tani dilakukan secara "simple random sampling". Pengambilan sampel dan anggota populasi dilakukan secara acak tanpa memperhatikan strata (tingkatan) dalam populasi tersebut. Berdasarkan cara tersebut terpilih 10 kelompok tani untuk dijadikan sampel penelitian. Pemilihan anggota kelompok tani dilakukan secara acak dengan mengambil paling sedikit sepuluh orang anggota kelompok tani dari tiap kelompok dengan ketentuan sekurang kurangnya dua orang pengurus kelompok dan yang lainnya adalah anggota kelompok, sehingga jumlah keseluruhan sampel adalah 100 orang petani.

\subsection{Validitas dan Reliabilitas Instrumen}

Pengujian validitas instrumen diperlukan untuk mendapatkan suatu data yang sesuai dengan tujuan penelitian. Menurut Arikunto (1998), reliabilitas menunjukkan keterpercayaan suatu alat pengumpul data karena instrumen tersebut sudah baik. Uji coba kuesioner dilakukan pada 20 petani responden yang tergabung dalam kelompok tani karya tani di Desa Jeruju Besar Kecamatan Sungai Kakap. Lokasi Desa ini bersebelahan dengan Desa Sungai Itik. Hasil uji coba instrumen menunjukkan bahwa pada signifikansi $\alpha=0,05$ dengan jumlah responden 20 orang responden petani diperoleh koefisien reliabilitas untuk 7 peubah sebesar 0,631 apabila dibandingkan dengan $\mathrm{r}$ tabel $(\mathrm{r}$ tabel 0,$05 ; 20=$ 0,456). Berdasarkan ketentuan uji statistik, kuesioner sudah valid dan reliabel untuk digunakan.

\subsection{Analisis Data}

Berdasarkan pada tujuan penelitian, model teoritis yang dikembangkan dan hipotesis yang diajukan, maka demikian pada penelitian ini dilakukan beberapa analisis: (1) Hasil perhitungan skor untuk melihat sebaran pada masing-masing variabel. Interpretasi data dilakukan atas hasil perhitungan skor dengan menggunakan kriteria interpretasi skor, (2) Analisis tabulasi silang dipergunakan untuk melihat proporsi dari masing masing variabel kategori, (3) Untuk melihat hubungan antar variabel karakteristik individu yang meliputi data pendidikan, pengalaman berusahatani, motivasi, tingkat pendapatan dan luas pemilikan lahan dengan komunikasi partisipatif dalam pelaksanaan Prima Tani dianalisis dengan menggunakan Rank Spearman (Riduan, 2004) dengan rumus seperti berikut :

$$
r_{s}=1-\frac{6 \sum_{i=1}^{n} d_{i} 2}{n\left(n^{2}-1\right)}
$$

Keterangan :

$$
\begin{aligned}
& \mathrm{r}_{\mathrm{s}}=\text { Nilai korelasi } \\
& d_{\mathrm{i}}^{2}=\text { Selisih antara peringkat } \\
& \mathrm{n}^{2}=\text { Pasangan data }
\end{aligned}
$$

\section{HASIL DAN PEMBAHASAN}

\subsection{Deskripsi Prima Tani di Desa Sungai Itik} Prima Tani merupakan Program Rintisan dan Akselerasi Pemasyarakatan Inovasi Teknologi Pertanian, yang dilaksanakan secara partisipatif oleh semua pemangku kepentingan pembangunan pertanian, dalam bentuk laboratorium agribisnis. Prima Tani dilaksanakan selama 5 tahun mulai tahun 2005 sampai dengan tahun 2009, dengan mengambil lokasi di 14 Provinsi mencakup 21 Laboratorium Agribisnis. Pada tahun 2006 dan 2007, Prima Tani dimulai pula di provinsi-provinsi lain, sehingga di setiap provinsi akan ada kegiatan Prima Tani.

Prima Tani pada tahun anggaran 20052009 difokuskan di 3 (tiga) agroekosistem yaitu: (1) agroekosistem lahan sawah, (2) agroekosistem lahan kering, dan (3) lahan rawa pasang surut. Salah satu wilayah di Indonesia yang dijadikan lokasi Prima Tani pada tahun 2005 adalah Propinsi Kalimantan Barat dengan lokasi di Desa Sungai Itik Kecamatan Sungai Kakap Kabupaten Pontianak. Desa Sungai Itik merupakan salah satu Desa dengan Sub 
Agroekosistem lahan rawa, dimana lahan ini mempunyai karakteristik berupa rawa yang dipengaruhi oleh pasang-surut air laut, terletak di dataran pantai, dengan tanah gambut atau mineral atau campuran keduanya. Model usahatani yang dikembangkan di Desa Sungai Itik merupakan model renovasi/lanjutan dari model agribisnis yang ada, sehingga pada akhirnya mencerminkan revitalisasi inovasi yang ada pada sistem dan usaha agribisnis saat ini. Prinsip dasar yang dikembangkan dalam model ini adalah: (1) reinventing system dan usaha agribisnis yang ada melalui reformasi sistem, usaha, pelayanan publik dan kelembagaan; (2) renovasi dan revitalisasi teknologi dan kelembagaan. Rancangan model inovasi yang dibangun berpijak pada kondisi sistem dan usaha agribisnis yang ada.

Luas sawah di Desa Sungai Itik sekitar 950 hektar dan sebagaian besar mata pencaharian penduduk dari padi sawah dan kelapa. Berdasarkan hasil PRA tahun 2005, permasalahan yang dijumpai pada daerah yang berbasis padi adalah rendahnya produktivitas dan pendapatan petani karena belum optimalnya pemanfaatan lahan dan tenaga. Sedangkan untuk daerah yang berbasis kelapa permasalahan yang dihadapi secara umum yaitu rendahnya produktivitas, harga jual kelapa dan produk olahannya (BPTP Kalbar, 2005). Peningkatkan produktivitas padi dilakukan dengan perbaikan budidaya dan pasca panen, sedangkan peningkatan pendapatan dilakukan dengan usahatani terpadu, dalam hal ini yang menguntungkan adalah padi, sapi dan ikan juga dengan pengolahan produk pertaniannya. Untuk meningkatkan produktivitas kelapa dilakukan dengan perbaikan teknik budidayanya dan pasca panen serta pengolahan sampingannya. Hingga saat penelitian ini dilakukan, usahatani yang dikembangkan dalam Prima Tani di Desa Sungai Itik adalah usahatani yang berbasis padi yang merupakan model usahatani lanjutan yang telah dilaksanakan pada tahun 2005, sedangkan usahatani yang berbasis kelapa masih dalam taraf identifikasi permasalahan dan kebutuhan teknologi.

Berdasarkan hasil PRA 2005, kelembagaan yang sudah ada di Sungai Itik sudah cukup lengkap, seperti pemerintah desa, kelompok tani, poliklinik desa, mesjid, RMU (lembaga pengolahan hasil), dan pasar yang cukup berperan, sedangkan PPL (lembaga penyuluhan), UPJA (lembaga alsintan) dan Credit Union (lembaga permodalan) perlu ditingkatkan peranannya agar lebih bermanfaat bagi petani. Sedangkan untuk lembaga sarana produksi (kios saprodi) berada diluar Desa Sungai Itik adalah 2 km dari Sungai Itik (BPTP Kalbar, 2005).

\subsection{Karakteristik Petani}

Petani yang terpilih menjadi sampel penelitian adalah petani yang tergabung dalam kelompok tani. Karakteristik individu petani yang diamati meliputi: pendidikan formal, pengalaman berusaha tani, motivasi, tingkat pendapatan dan luas pemilikan lahan.

Petani yang mengikuti Prima Tani adalah petani dengan tingkat pendidikan yang relatif rendah. Pendidikan petani 66 persen berpendidikan Sekolah Dasar/Madrasah Ibtidaiyah. Sedangkan berpendidikan SMP/Madrasah Tsanawiyah berjumlah 22 persen dan SMA/Madrasah Aliyah berjumlah 10 persen. Rendahnya tingkat pendidikan petani hendaknya perlu dicermati oleh Tim pembina di lapangan agar proses komunikasi antara petani dengan penyuluh dan Tim Prima Tani dapat berjalan sesuai dengan yang diharapkan, sehingga apa yang direncanakan dan dilaksanakan dalam Prima Tani dapat tercapai. Pembina di lapangan perlu memperhatikan kemampuan petani dalam menyerap berbagai materi pengetahuan yang disampaikan, disamping itu pembina di lapangan diharapkan dapat mengemas dan menyampaikan informasi secara sederhana dan menarik sehingga dapat dipahami dan dilaksanakan oleh petani.

Petani yang mengikuti Prima Tani mempunyai motivasi yang tinggi untuk mengikuti model usahatani terpadu yang dikembangkan dalam Prima Tani. Hasil penelitian menunjukkan, bahwa hampir sebagian besar responden sangat tertarik $(2,1-3)$ yaitu sebesar 72 persen dan tertarik $(1,1-2)$ sebesar 27 persen untuk mengikuti Prima Tani, sedangkan 1 persen tidak tertarik. Ketertarikan petani karena Prima Tani merupakan hal yang baru dan petani berharap dengan adanya Prima Tani ini dapat meningkatkan pendapatannya. Luas lahan yang dimiliki oleh petani dalam melakukan kegiatan usahatannya bervariasi. Lahan terkecil yang dimiliki oleh petani adalah $2.500 \mathrm{~m}^{2}$ dan terluas adalah $30.000 \mathrm{~m}^{2}$. Sebagian besar petani dalam penelitian ini memiliki lahan berkisar antara 2500-30.000 $\mathrm{m}^{2}$. Lahan yang ada pada umumnya digunakan untuk bercocok tanam padi. Sebagian besar petani di Desa Sungai Itik telah menerapkan pola dua kali tanam dalam satu tahun yaitu musim rendengan dan musim gadu. 
Pendapatan petani responden dalam satu bulan terakhir berkisar antar Rp. 150.0002.000.000,-. Pendapatan terbesar petani responden dalam mengelola usahataninya terbesar berada pada kisaran Rp.1.000.0001.500 .000 ,- perbulan dengan proporsi sebesar 40 persen. Perbedaan pendapatan diantara responden disebabkan karena perbedaan luas lahan usahatani yang dikelolanya, sehingga akan mempengaruhi penghasilan setiap petani.

\subsection{Komunikasi Partisipatif dalam Pelaksanaan Prima Tani}

Prima Tani di Desa Sungai Itik dilaksanakan secara partisipatif dengan melibatkan BPTP dan Dinas instansi terkait mulai dari tingkat Propinsi, Kabupaten dan Kecamatan, dengan sasarannya adalah petani. Komunikasi partisipatif dalam pelaksanaan Prima Tani antara Tim dari Prima Tani dengan petani dilakukan untuk mengetahui apa yang menjadi keinginan dan kebutuhan petani sehingga dapat dijadikan sebagai acuan dalam merencanakan inovasi teknologi pertanian yang sesuai dengan karakteristik lokal spesifik dan petani penggunanya. Tahapan yang perlu dilaksanakan dalam komunikasi partisipatif dalam Prima Tani adalah sebagai berikut:

\subsection{Penumbuhan Ide}

Penumbuhan ide merupakan suatu proses atau kegiatan dalam mensosialisasikan dan memperkenalkan Prima Tani kepada masyarakat tani, untuk memperoleh masukan dan keinginan serta dukungan petani terhadap Prima Tani. Sosialisasi ini selain bertujuan untuk mengenalkan Prima Tani yang dilaksanakan di desa juga untuk menumbuhkan ide apa sebenarnya yang di inginkan berkaitan dengan usahatani yang dijalaninya. Gambaran penumbuhan ide pada petani dalam rangka pelaksanaan Prima Tani dapat dilihat dari bagaimana respons dan keterlibatan petani dalam proses penumbuhan ide yang dilaksanakan di desa. Respons petani ini dapat dilihat dari bagaimana kehadiran petani dalam sosialisasi tentang Prima Tani, bagaimana upaya mereka dalam mendengarkan dan memahami penjelasan tentang Prima Tani, bagaimana proses komunikasi partisipatif berlangsung yang dapat dilihat dari respons petani pada saat diberikan kesempatan mengajukan pertanyaan, bagaimana keterlibatan petani dalam turut memberikan usul, saran dan masukan sesuai dengan permasalahan dan keinginan petani serta dukungan petani dalam pelaksanaan Prima Tani.
Tabel 1. Keterlibatan Petani dalam Penumbuhan Ide

\begin{tabular}{clc}
\hline No & \multicolumn{1}{c}{ P e r $\mathbf{n}$ y a t a a $\mathbf{~}$} & $\begin{array}{c}\text { Rata-rata } \\
\text { skor }\end{array}$ \\
\hline 1. & $\begin{array}{l}\text { Menghadiri sosialisasi Prima Tani } \\
\text { 2. }\end{array}$ & 3,79 \\
& $\begin{array}{l}\text { Mendengarkan dan berusaha } \\
\text { memahami penjelasan Prima Tani }\end{array}$ & 3,77 \\
3. $\begin{array}{l}\text { Petani diberikan kesempatan } \\
\text { bertanya }\end{array}$ & 4,09 \\
4. $\begin{array}{l}\text { Turut memberikan masukan } \\
\text { sesuai permasalahan dan } \\
\text { keinginan petani }\end{array}$ & 4,15 \\
5. Mendukung pelaksanaan Prima \\
$\quad$ Tani
\end{tabular}

Dalam kegiatan sosialisasi, petani menyatakan mendengarkan dan berusaha memahami materi sosialisasi yang disampaikan. Hal ini disebabkan karena Prima Tani merupakan program yang baru sehingga petani yang hadir perlu mendapat penjelasan tentang program tersebut, terutama berkaitan dengan pola usahatani yang dijalankannya selama ini. Dalam kesempatan ini pula petani diberikan kesempatan untuk bertanya dan respons petani untuk mengajukan pertanyaan sangat tinggi. Ini menunjukkan bahwa petani sangat antusias untuk mengetahui dan memahami tentang Prima Tani yang akan dilaksanakan diwilayah nya. Dengan pahamnya petani tentang Prima Tani ini, maka diharapkan akan tumbuh dan berkembang ide baru sehingga dapat memberikan masukan dalam mengembangkan model usahatani yang sesuai dengan kondisi dan karakteristik lokal spesifik serta sesuai dengan keinginan dan kebutuhan petani.

Petani menyatakan turut memberikan masukan kepada Tim Prima Tani menyangkut program yang akan dilaksanakan di desa tersebut. Hal Ini menunjukkan bahwa dalam tahapan komunikasi partisipatif keterlibatan petani cukup tinggi. Sedangkan dukungan petani terhadap pelaksanaan Prima Tani di desa juga sangat tinggi. Dengan dukungan yang tinggi diharapkan program Prima Tani dapat dilaksanakan sesuai dengan harapan dan dapat mengembangkan ideide yang baru untuk mendukung Prima Tani.

Tabel 1 menunjukkan bahwa keterlibatan petani dalam komunikasi partisipatif pada penumbuhan ide skor rata rata tinggi sebesar 
4,03. Nilai ini mengindikasikan bahwa dalam proses komunikasi partisipatif pada penumbuhan ide keterlibatan petani sangat tinggi. Petani mendukung dan ikut terlibat aktif dalam tahapan proses penumbuhan ide.

\subsubsection{Perencanaan Program}

Perencanaan program merupakan kegiatan komunikasi partisipatif dalam Prima Tani untuk mengidentisifikasi suatu wilayah dan permasalahannya dalam usahatani padi, tanaman perkebunan, hortikultura/sayuran, ternak dan ikan serta mengidentisifikasi peluang dan solusi dalam rangka menemukan model usahatani yang tepat untuk meningkatkan pendapatan petani.

Keterlibatan petani dalam perencanaan program yang akan dikembangkan di desa dapat dilihat pada Tabel 2.

Tabel 2. Keterlibatan Petani dalam Perencanaan Program

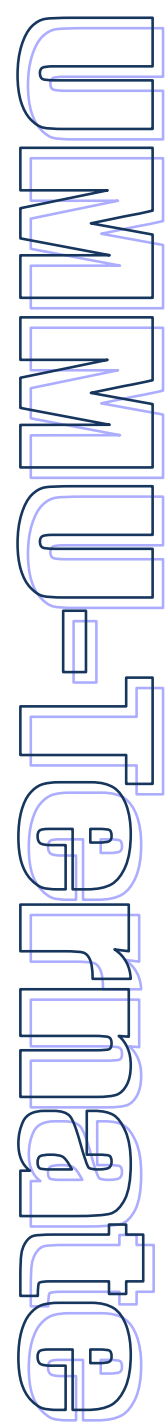

\begin{tabular}{clc}
\hline No & \multicolumn{1}{c}{ P e r $\mathbf{n}$ y a t a a $\mathbf{~}$} & $\begin{array}{c}\text { Rata-rata } \\
\text { skor }\end{array}$ \\
\hline 1. & $\begin{array}{l}\text { Menghadiri pendataan, identifikasi } \\
\text { wilayah dan masalah usahatani }\end{array}$ & 3,63 \\
2. & $\begin{array}{l}\text { Memperhatikan pada saat dilakukan } \\
\text { pendataan, identifikasi wilayah } \\
\text { dan masalah usahatani }\end{array}$ & 3,58 \\
3. $\quad \begin{array}{l}\text { Petani diberikan kesempatan } \\
\text { bertanya }\end{array}$ & 4,18 \\
4. $\begin{array}{l}\text { Turut mengajukan usul dan saran } \\
\text { pada saat pendataan, identifikasi } \\
\text { wilayah dan masalah usahatani }\end{array}$ & 3,76 \\
5. $\quad \begin{array}{l}\text { Mendukung hasil pendataan dan } \\
\text { identifikasi wilayah serta rencana } \\
\text { yang akan dikembangkan }\end{array}$ & 4,26 \\
\hline & Rata-rata \\
\hline Keterangan: $n=100$ & 3,88 \\
\hline
\end{tabular}

Perencanaan program dalam Prima Tani bertujuan untuk mengetahui dan mengidentifikasi peluang dan solusi dalam merumuskan model usahatani yang yang tepat sesuai keinginan dan karakteristik lokasi Prima Tani. Untuk mengetahui bagaimana gambaran perencanaan program dalam pelaksanaan Prima Tani, maka dapat dilihat bagaimana respons dan keterlibatan petani dalam proses perencanaan yang dilaksanakan di desa. Respons petani ini dapat dilihat dari bagaimana kehadiran mereka dalam menghadiri pendataan, identifikasi wilayah serta identifikasi masalah usahatani, bagaimana perhatian petani pada saat dilakukan pendataan, bagaimana proses komunikasi partisipatif berlangsung yang dapat dilihat dari respon petani pada saat diberikan kesempatan mengajukan pertanyaan, bagaimana keterlibatan petani dalam turut memberikan usul, saran dan masukan sesuai dengan permasalahan dan keinginan petani serta bagaimana dukungan mereka terhadap hasil pendataan dan identifikasi wilayah serta rencana yang akan dikembangkan dalam pelaksanaan Prima Tani.

Berdasarkan Tabel 2, keterlibatan petani dalam proses perencanaan model usahatani terpadu adalah tinggi. Skor rata-rata keterlibatan petani dalam perencanaan program tinggi dengan rata-rata sebesar 3,88. Berdasarkan wawancara yang penulis lakukan di lapangan dengan penyuluh dan petugas lapangan lainnya dalam kegiatan perencanaan memang melibatkan hampir seluruh petani terutama pengurus kelompok tani dan orang yang dipandang mempunyai pengaruh dan mampu di wilayah Desa Sungai Itik. Tetapi tidak semua petani hadir dalam kegiatan pendataan dan identifikasi, selain itu juga ada petani yang hadir dalam kegiatan tersebut tetapi mereka tidak aktif berpartisipasi dalam proses identifikasi dan perencanaan.

\subsubsection{Pelaksanaan Program yang Dihasilkan}

Untuk mengetahui bagaimana gambaran pelaksanaan model usahatani terpadu dalam Prima Tani, dapat dilihat bagaimana respons dan keterlibatan petani dalam proses pelaksanaan teknologi inovatif model usahatani terpadu di desa. Respons dan keterlibatan petani ini dapat dilihat dari bagaimana kehadiran mereka dalam pelatihan model usahatani terpadu, kehadirannya dalam praktek model percontohan usahatani terpadu, kehadirannya bersama penyuluh dalam melaksanakan model usahatani terpadu, perhatian yang diberikan dalam pelatihan, model percontohan dan pendampingan dalam pelaksanaan model usahatani terpadu. Untuk mengetahui bagaimana keterlibatan petani dalam proses komunikasi partisipatif pelaksanaan model usahatani terpadu dapat dilihat dari respon petani pada saat diberikan kesempatan mengajukan pertanyaan pada kegiatan pelatihan, model percontohan maupun pada saat pendampingan oleh penyuluh, bagaimana keterlibatan petani dalam memberikan usul, saran, masukan sesuai dengan permasalahan dan keinginan petani pada saat pelatihan, pelaksanaan model percontohan dan pendampingan serta bagaimana tanggapan petani terhadap apa yang menjadi keinginan mereka dalam pelaksanaan model usahatani terpadu di lahan usahataninya. 
Pelaksanaan model usahatani terpadu ini diawali dengan pertemuan sistem produksi yang dihadiri oleh petani di lokasi Prima Tani. Berdasarkan informasi yang penulis peroleh dari penyuluh dan petugas lapangan dari BPTP, kegiatan pertemuan sistem produksi untuk tahun 2006 telah dilaksanakan sebanyak dua kali yaitu pada bulan Maret dan Mei 2006. Tujuan dari pertemuan ini adalah untuk mengenalkan kepada petani mengenai teknik budidaya tanaman yang baik agar mereka memahami dan selanjutnya menerapkan teknologi yang diberikan sesuai anjuran serta diharapkan dapat memperoleh umpan balik.

Pernyataan petani berkaitan dengan keterlibatannya dalam pelaksanaan model usahatani terpadu dapat dilihat pada Tabel 3.

Tabel 3. Keterlibatan Petani dalam Pelaksanaan Model Usahatani Terpadu

\begin{tabular}{|c|c|c|}
\hline No & Perny a ta n & $\begin{array}{c}\text { Rata- } \\
\text { rata }\end{array}$ \\
\hline 1. & $\begin{array}{l}\text { Menghadiri penyampaian pelatihan } \\
\text { model usahatani terpadu }\end{array}$ & 3,75 \\
\hline 2. & $\begin{array}{l}\text { Menghadiri praktek model percontohan } \\
\text { model usahatani terpadu }\end{array}$ & 3,81 \\
\hline 3. & $\begin{array}{l}\text { Hadir bersama penyuluh melakukan } \\
\text { kegiatan model usahatani terpadu }\end{array}$ & 3,75 \\
\hline 4. & $\begin{array}{l}\text { Memperhatikan model usahatani yang } \\
\text { disampaikan melalui pelatihan, model } \\
\text { percontohan maupun pendampingan } \\
\text { oleh penyuluh }\end{array}$ & 3,78 \\
\hline 5. & $\begin{array}{l}\text { Petani diberikan kesempatan bertanya } \\
\text { pada saat kegiatan pelatihan, model } \\
\text { percontohan dan pendampingan oleh } \\
\text { penyuluh }\end{array}$ & 3,96 \\
\hline 6. & $\begin{array}{l}\text { Mengajukan pertanyaan pada saat } \\
\text { pelatihan, model percontohan dan } \\
\text { pendampingan oleh penyuluh }\end{array}$ & 3,73 \\
\hline 7. & $\begin{array}{l}\text { Mengajukan usul dan saran pada saat } \\
\text { pelatihan, model percontohan dan } \\
\text { pendampingan oleh penyuluh }\end{array}$ & 3,87 \\
\hline 8. & $\begin{array}{l}\text { Usul dan saran yang disampaikan oleh } \\
\text { petani diterima dan dijadikan bahan } \\
\text { pertimbangan penyuluh }\end{array}$ & 4,10 \\
\hline & Rata-rata & 3,84 \\
\hline
\end{tabular}

Berdasarkan pengamatan dan wawancara yang penulis lakukan selama penelitian di lokasi Prima Tani, penyuluh dan petugas dari BPTP dan petugas Dinas/Instansi terkait lainnya cukup aktif mengunjungi dan mendampingi serta melakukan pengawalan teknologi yang didiseminasikan kepada petani dalam setiap kegiatan usahatani yang dilaksanakan.

Keterlibatan petani dalam komunikasi partisipatif pada pelaksanaan model usahatani terpadu adalah tinggi, hal ini dapat dilihat dari skor rata-rata petani dalam pelaksanaan program dengan rata-rata sebesar 3,84. Tingginya keterlibatan petani dalam pelaksanaan model usahatani terpadu belum menjamin bahwa apa yang disampaikan oleh penyuluh dilaksanakan oleh petani, karena terdapat faktor-faktor lain yang mempengaruhi perilaku petani dalam menerapkan suatu teknologi maupun inovasi. Salah satunya adalah kemampuan baik modal maupun SDM yang ada pada petani serta motivasi dan keinginannya.

\subsubsection{Penilaian terhadap Program yang Dihasilkan}

Penilaian program yang dihasilkan merupakan kegiatan komunikasi yang dilakukan antara Tim Prima Tani dengan petani, dimana petani diberikan kebebasan untuk menilai model usahatani terpadu yang dilaksanakan. Untuk mengetahui bagaimana gambaran penilaian terhadap model usahatani terpadu yang dihasilkan dalam Prima Tani maka dapat dilihat bagaimana respons dan keterlibatan petani dalam melakukan penilaian terhadap program yang dilaksanakan. Respon dan keterlibatan petani ini dapat dilihat dari keaktifannya dalam melakukan peninjauan lokasi pelaksanaan model usahatani terpadu, keaktifannya dalam mendampingi penyuluh melakukan pengamatan lahan usahatani, keaktifannya dalam mengamati dan menilai lahan yang dikelolanya serta keaktifannya dalam memberikan informasi dan dukungan terhadap model usahatani terpadu yang dikembangkan.

Pernyataan tentang keterlibatan petani dalam melakukan penilaian terhadap program yang diimplementasikan dalam Prima Tani dapat dilihat pada Tabel 4 .

Tabel 4. Keterlibatan Petani dalam Penilaian Program yang Dilaksanakan

\begin{tabular}{clc}
\hline No & \multicolumn{1}{c}{ P e r $\mathbf{n}$ y a t a a $\mathbf{~}$} & $\begin{array}{c}\text { Rata-rata } \\
\text { skor }\end{array}$ \\
\hline 1. & $\begin{array}{l}\text { Pernah melakukan peninjauan } \\
\text { lokasi pelaksanaan Prima Tani }\end{array}$ & 3,85 \\
2. & $\begin{array}{l}\text { Mendampingi penyuluh melakukan } \\
\text { pengamatan lahan usahatani }\end{array}$ & 3,96 \\
3. $\quad \begin{array}{l}\text { Mengamati dan menilai lahan } \\
\text { usahatani yang dikelola }\end{array}$ & 3,70 \\
4. $\begin{array}{l}\text { Memberikan informasi } \\
\text { pelaksanaan model usahatani } \\
\text { terpadu kepada penyuluh }\end{array}$ & 3,78 \\
5. $\quad \begin{array}{l}\text { Mendukung model usahatani } \\
\text { terpadu yang dikembangkan di } \\
\text { desa }\end{array}$ & 4,46 \\
\hline
\end{tabular}




\begin{tabular}{cc}
\hline Rata-rata & 3,95 \\
\hline $\begin{array}{c}\text { Keterangan: } n=100 \\
\text { Keterlibatan petani dalam melakukan }\end{array}$
\end{tabular}
penilaian terhadap model usahatani yang dijalankan dilihat dari apakah mereka pernah melakukan peninjauan lokasi baik model usahatani terpadu yang dijalankannya maupun yang dilakukan petani lainnya di desa. Dengan melakukan peninjauan lokasi berarti mereka secara tidak langsung turut memberikan penilaian terhadap pelaksanaan model usaha tani yang dijalankan. Petani pada umunya pernah melakukan peninjauan lokasi pelaksanaan Prima Tani, hal ini disebabkan karena lokasi Prima Tani tidak jauh dari lingkungannya, sehingga memudahkan petani dalam melihat/meninjau model usahatani terpadu yang dilaksanakan di desa. Petani sebagian besar aktif mendampingi penyuluh melakukan pengamatan lahan usahatani yang dikelola. Hasil pengamatan yang dilakukan oleh petani diinformasikan juga kepada penyuluh. Pernyataan ini terbukti dari informasi yang disampaikan penyuluh bahwa petani baik secara formal maupun informal selalu melakukan komunikasi dengan penyuluh menyangkut usahatani yang dijalaninya maupun menyangkut masalah-masalah lainnya.

Berdasarkan uraian di atas serta Tabel 4 maka dapat dikatakan bahwa keterlibatan petani dalam melakukan penilaian program yang dihasilkan tinggi. Hal ini terbukti dan dapat dilihat dari nilai skor rata-rata petani dalam penilaian program yang sangat tinggi dengan rata-rata sebesar 3,95 .

\subsection{Hubungan Karakteristik Individu Petani dengan Komunikasi Partisipatif}

Komunikasi partisipatif dalam Prima Tani salah satu tujuannya adalah untuk menemukan dan merumuskan model usahatani terpadu yang sesuai dengan karakteristik lokal spesifik dan keinginan petani. Petani dilibatkan secara langsung dalam proses penumbuhan ide, perencanaan, pelaksanaan dan penilaian model usahatani yang dikembangkan. Karakteristik petani akan mempengaruhi proses komunikasi partisipatif yang akan menghasilkan suatu model usahatani yang akan dilaksanakan dan dikembangkan dilokasi Prima Tani. Hal ini disebabkan karakteristik individu petani akan mempengaruhi keberhasilan pelaksanaan Prima Tani dan sangat terkait dengan bagaimana proses komunikasi partisipatif yang terjadi antara Tim Prima Tani dengan petani dilokasi Prima Tani. Untuk mengetahui bagaimana hubungan kedua variabel tersebut, maka dilakukan uji dengan menggunakan analisis Korelasi Rank Spearman.

Korelasi antara karakteristik individu dengan komunikasi partisipatif dalam pelaksanaan Prima Tani dapat dilihat pada Tabel 5.

Tabel 5. Hubungan Karakteristik Individu Petani dengan Komunikasi Partisipatif dalam Pelaksanaan Prima Tani

\begin{tabular}{|c|c|c|c|c|c|}
\hline \multirow[t]{2}{*}{ No } & \multirow[t]{2}{*}{ Karakteristik Individu Petani } & \multicolumn{4}{|c|}{$\begin{array}{c}\text { Komunikasi Partisipatif Dalam Pelaksanaan } \\
\text { Prima Tani }\end{array}$} \\
\hline & & Penumbuhan Ide & $\begin{array}{l}\text { Perencanaan } \\
\text { Program }\end{array}$ & $\begin{array}{l}\text { Pelaksanaan } \\
\text { Program }\end{array}$ & $\begin{array}{l}\text { Penilaian } \\
\text { Program }\end{array}$ \\
\hline 1. & Pendidikan & 0,143 & 0,042 & 0,100 & 0,006 \\
\hline 2. & Pengalaman usaha tani & 0,002 & 0,135 & $-0,069$ & 0,067 \\
\hline 3. & Motivasi & $0,243^{*}$ & 0,152 & 0,176 & 0,087 \\
\hline 4. & Tingkat pendapatan & 0,175 & $0,200^{*}$ & $0,312^{* *}$ & $0,240^{*}$ \\
\hline 5. & Luas pemilikan lahan & $-0,001$ & 0,045 & 0,095 & 0,049 \\
\hline
\end{tabular}

Ket ${ }^{\star} \quad=$ Signifikan pada taraf nyata $\alpha 0,05$

$\star \star$ = Signifikan pada taraf nyata a 0,01

Tabel 5 menunjukkan Pendidikan petani tidak mempunyai hubungan nyata dengan semua peubah dalam komunikasi partisipatif. Artinya keterlibatan petani dalam penumbuhan ide, perencanaan program, pelaksanaan program dan penilaian program tidak dipengaruhi oleh tingkat pendidikan petani. Keterlibatan petani sama saja antara petani yang mempunyai pendidikan yang rendah maupun petani dengan pendidikan yang tinggi. Dengan demikian $\mathrm{H}_{1}$ pada korelasi antara peubah pendidikan dengan penumbuhan ide, 
perencanaan program, pelaksanaan dan penilaian program ditolak.

Pengalaman usahatani tidak mempunyai hubungan nyata dengan semua peubah dalam komunikasi partisipatif. Artinya keterlibatan petani dalam penumbuhan ide, perencanaan program, pelaksanaan program dan penilaian program tidak dipengaruhi oleh pengalaman usahatani petani. Keterlibatan petani sama saja antara petani yang telah lama berusahatani dengan petani yang belum lama dalam berusahatani. Dengan demikian $\mathrm{H}_{1}$ pada korelasi antara pengalaman berusahatani dengan penumbuhan ide, perencanaan program, pelaksanaan dan penilaian program ditolak.

Motivasi tidak mempunyai hubungan nyata dengan peubah perencanaan program, pelaksanaan dan penilaian program. Artinya keterlibatan petani dalam perencanaan program, pelaksanaan program dan penilaian program tidak dipengaruhi oleh motivasi petani. Keterlibatan petani sama saja antara petani yang mempunyai motivasi yang rendah maupun petani dengan motivasi yang tinggi. Dengan demikian $\mathrm{H}_{1}$ pada korelasi antara motivasi dengan perencanaan program, pelaksanaan dan penilaian program ditolak. Sedangkan pada penumbuhan ide, motivasi berhubungan nyata. Artinya semakin tinggi motivasi petani mengikuti Prima Tani semakin tinggi keterlibatannya dalam penumbuhan ide. Petani sangat tertarik terhadap model usahatani yang akan dikembangkan di lokasi Prima Tani karena berkaitan dengan keinginan dan kebutuhannya. Dengan demikian $\mathrm{H}_{1}$ pada korelasi antara motivasi dengan penumbuhan ide diterima.

Tingkat pendapatan petani berhubungan nyata dengan perencanaan program, berhubungan sangat nyata dengan pelaksanan program, dan berhubungan nyata dengan penilaian program, Ini artinya semakin tinggi tingkat pendapatan petani maka keterlibatan mereka dalam turut merencanakan model usahatani yang akan dikembangkan di desa, keterlibatannya dalam pelaksanaan program dan penilaian program semakin tinggi. Kenyataan di lapangan, petani yang mempunyai tingkat pendapatan yang lebih dibanding petani lainnya pada umumnya dijadikan panutan oleh petani lainnya karena secara ekonomi mereka dianggap lebih dari yang lainnya. Dengan demikian $\mathrm{H}_{1}$ pada korelasi antara tingkat pendapatan dengan perencanaan program, pelaksanaan program dan penilaian program diterima. Sedangkan korelasi antara tingkat pendapatan dengan penumbuhan ide ditolak.

Luas pemilikan lahan tidak mempunyai hubungan nyata dengan semua peubah dalam komunikasi partisipatif. Artinya keterlibatan petani dalam penumbuhan ide, perencanaan program, pelaksanaan program dan penilaian program tidak dipengaruhi oleh luas pemilikan lahan petani. Keterlibatan petani sama saja antara petani yang mempunyai luas lahan yang kecil maupun petani dengan luas lahan yang besar. Dengan demikian $\mathrm{H}_{1}$ pada korelasi antara luas lahan dengan penumbuhan ide, perencanaan program, pelaksanaan dan penilaian program ditolak.

Berdasarkan pada uraian yang dikemukakan di atas, menunjukkan bahwa ada beberapa peubah pada korelasi antara karakteristik individu petani dengan komunikasi partisipatif dalam pelaksanaan Prima Tani yang dapat diterima dan ditolak. Korelasi antara karakteristik individu petani dengan komunikasi partisipatif dalam pelaksanaan Prima Tani lebih banyak yang ditolak dibandingkan dengan yang diterima. Dengan demikian $\mathrm{H}_{1}$ korelasi antara karakteristik individu petani dengan komunikasi partisipatif dalam pelaksanaan Prima Tani ditolak.

\section{KESIMPULAN DAN SARAN}

\subsection{Kesimpulan}

1. Komunikasi partisipatif dalam pelaksanaan Prima Tani terbukti efektif dalam meningkatkan pengetahuan dan sikap petani terhadap model usahatani terpadu yang dikembangkan dalam pelaksanaan Prima Tani di Desa Sungai Itik Kecamatan Sungai Kakap Kabupaten Pontianak.

2. Faktor-faktor karakteristik individu yang menentukan keefektifan komunikasi partisipatif dalam pelaksanaan Prima Tani adalah motivasi dan tingkat pendapatan.

\subsection{Saran}

Untuk lebih meningkatkan keberhasilan Prima Tani, maka disarankan:

1. Untuk mempercepat perubahan perilaku petani dalam menerapkan inovasi dalam model usahatani terpadu maka perlu dilakukan percontohan model usahatani dan sosialisasi perlu ditingkatkan agar penerapan inovasi merata pada setiap kelompok tani.

2. Perlu peningkatan koordinasi dan dukungan program maupun permodalan dari berbagai 
institusi yang terkait dengan Prima Tani agar tujuan Prima Tani dapat tercapai.

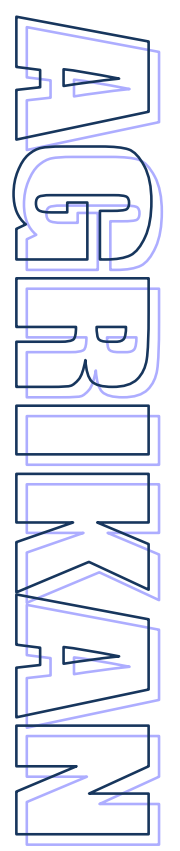

\section{DAFTAR PUSTAKA}

Arikunto, Ny. Suharsimi., 1998. Prosedur Penelitian, Suatu Pendekatan Praktik, Jakarta: Edisi Revisi IV,Bina Aksara.

BPTP Kalimantan Barat., 2005. Laporan Akhir Kelembagaan Program Rintisan dan Akselerasi Pemasyarakatan Inovasi Teknologi Pertanian (Prima Tani) di Lahan Pasang Surut Kalimantan Barat.Balai Pengkajian Teknologi Pertanian. Kalimantan Barat.

BPTP Kalimantan Barat, 2005. Laporan Akhir Usaha Tani Program Rintisan dan Akselerasi Pemasyarakatan Inovasi Teknologi Pertanian (Prima Tani) di Lahan Pasang Surut Kalimantan Barat. Balai Pengkajian Teknologi Pertanian. Kalimantan Barat.

Departemen Pertanian Republik Indonesia, 2006. Pedoman Umum Prima Tani. Jakarta

Riduwan., 2004. Metode dan Teknik Menyusun Tesis. Alfabeta Bandung.

Singarimbun, Masri dan Sofian Efendi, ed, 1987., Metode Penelitian Survey, Jakarta: LP3ES.

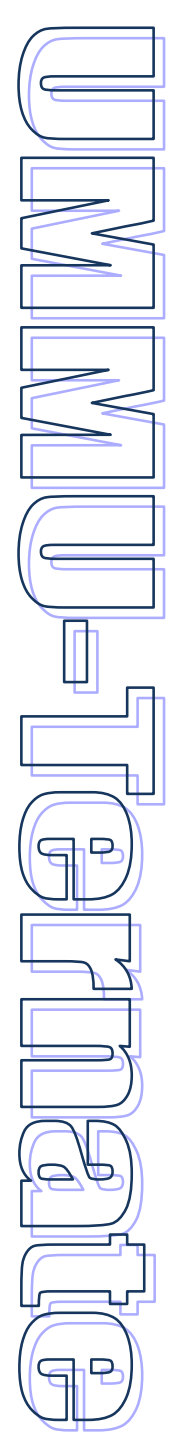

